\title{
PERSONALITY: HOW DOES IT IMPACT TEACHERS' ORGANIZATIONAL COMMITMENT?
}

\author{
Purwani Puji Utami ${ }^{*}$, Alexius Dwi Widiatna ${ }^{2}$, Syamzah Ayuningrum ${ }^{1}$, \\ Arbiana Putri ${ }^{1}$, Herlyna ${ }^{3}$, Adisel ${ }^{4}$ \\ ${ }^{1}$ STKIP Kusuma Negara, Indonesia \\ ${ }^{2}$ STKIP Widya Yuwana, Indonesia \\ ${ }^{3}$ STBA Pertiwi, Indonesia \\ ${ }^{4}$ IAIN Bengkulu, Indonesia \\ *e-mail: purwani_puji@stkipkusumanegara.ac.id
}

\begin{abstract}
Teacher organizational commitment is a determining factor for achieving quality education. It is believed that teacher personality is one of the main factors which either increase or decrease organizational commitment. This research aims to examine the effects of teacher personality on their organizational commitment. The quantitative approach was employed with the survey method. The samples were selected using the simple random technique by applying the Slovin formula. The participants of this study were 83 civil servant teachers at public senior high schools located in East Jakarta. The data of this study were collected through a survey and then analyzed using Path analysis. The results of the analysis show that $t_{\text {count }}$ is higher than $t_{\text {table }}(4.329>2.64)$. This result means that $H_{0}$ is rejected while $H_{1}$ is accepted. The hypothesis testing shows that personality has a positive direct effect on teacher organizational commitment. Furthermore, it is proven that there are three traits influencing teacher personality, namely emotional stability (33.98\%), extroversion (33.56\%), and openness to experience (32.46\%). Meanwhile, the main factors influencing organizational commitment are employee engagement (33.74\%), moral responsibility $(33.55 \%)$, and loyalty $(32.71 \%)$. Based on the result of this study, it is suggested that school principals take teacher personality into account in order to improve teacher organizational commitment at schools.
\end{abstract}

\section{Keywords: organizational commitment, personality, teacher.}

\section{KEPRIBADIAN: BAGAIMANA PENGARUHNYA TERHADAP KOMITMEN ORGANISASI GURU?}

\begin{abstract}
Abstrak: Komitmen organisasi guru adalah faktor penentu dalam keberhasilan pendidikan yang berkualitas. Kepribadian guru merupakan salah satu faktor utama yang diyakini dapat meningkatkan atau menurunkan komitmen organisasi. Penelitian ini bertujuan untuk mendeskripsikan peranan kepribadian komitmen organisasi. Sampel dipilih menggunakan teknik acak sederhana dengan memanfaatkan rumus Slovin. Sebanyak 83 guru PNS SMK di Jakarta Timur dilibatkan dalam penelitian ini. Data yang dikumpulkan melalui kuesioner dianalisis dengan analisis jalur. Hasilnya menunjukkan bahwa $t_{\text {hitung }}$ lebih besar dibanding $t_{\text {tabel }}(4,329>2,64)$. Hasil ini mengarah pada penolakan $H_{0}$ dan penerimaan $H_{l}$. Hasil pengujian hipotesis menyimpulkan bahwa kepribadian memiliki pengaruh langsung positif terhadap komitmen organisasi guru. Selain itu, terbukti ada tiga sifat yang mempengaruhi kepribadian, yakni kestabilan emosi $(33,98 \%)$, keramahan $(33,56 \%)$ dan keterbukaan terhadap pengalaman $(32,46 \%)$. Sementara faktor utama yang mempengaruhi komitmen organisasi adalah: keterlibatan untuk tetap menjadi karyawan (33,74\%); tanggung jawab moral (33,55\%); dan kesetiaan individu terhadap organisasi $(32,71 \%)$. Studi ini kemudian merekomendasikan bahwa kepala sekolah bertanggung jawab untuk memperhatikan kepribadian guru dalam upaya meningkatkan komitmen organisasi guru di sekolah.
\end{abstract}

Kata Kunci: komitmen organisasi, kepribadian, guru.

\section{INTRODUCTION}

The Industrial Revolution 4.0 era emerges stricter competition among organizations both in national or international level. Facing such situation and condition, organizations should determine strategies and release management 
policy, particularly on the development of human resources. The enhancement of human resource understanding and management which is claimed as one of the three management challenges (Abdullah, 2009), is obligatory to promote schools' quality.

As an organization, it is inevitable for schools to take momentous changes to anticipate any globalization demand including effective leadership management. This is as an attempt to motivate school staffs specifically teachers to give their best in work. As far as it is concerned, teachers' presence is the major asset of school for the sake of quality advancement.

Teachers should possess eminent commitment to carry on their duties and responsibility as educators at schools. Without mutual commitment, school goals will be unattainable to reach (Pramudjono, 2015). Such commitment is well known as organizational commitment, in which individuals are expected to be able to emerge and realize ideas for the accomplishment of organization vision and mission. It can be merely defined that organizational commitment is individuals' psychological attachment to their organizations marked by trust and acceptance to organizational values and characteristics, as well as intense motivation and desire to reach vision and mission for organizational existence (Situmorang, 2014). The concept of organizational commitment has been being a particular concern based on a premise that individuals are related to their organizations as relative power of individual identification within a specific organization (Suriansyah, 2014). Lovakov (2016) asserts that an employee whose high organizational commitment is a 'great warrior' for his organization.

Wherefore, school principals ought to review and evaluate teacher commitment for continuant betterment of school quality. Variety of attempt should be applied to keep teacher work hard and committed. This matter becomes one of the considerations behind a public policy of Jakarta Governance to pay special attention to their teachers particularly civil servant teachers; one of them is by granting them with regional performance allowance. Nonetheless, Kumorotomo (2011) finds out that the allowance is distributed based on structural position, not functional or objective performance indicators. Hence, the possibility of significant performance improvement is not promising.

The fact mentioned above becomes an interesting point to investigate; that to foster teacher organizational commitment is not only by granting them allowance. More analysis on their personality is worth to apply. Excellent personality is underlined as one of the competencies to possess by teachers based on Law of the Republic of Indonesia Number 14 Year 2005 on the subject of teachers and lecturers. Personality, to Kinicky \& Fugate (2016), is the combination of firmed physical, behavioral, and mental characteristics which signal one's unique identity. While Robbins \& Judge (2017) view personality as an individual typical reaction and interaction with other people. Providing more complex perspective, McShane \& von Glinow (2015) perceive personality as pattern of thoughts, emotions, and behaviors that distinguish someone by the involvement of psychological processes. Those concepts of personality certainly signal that personality involves one's physical performance, behavioral, mental to react and interact with people in his/ her surroundings.

Touching on teacher personality, it unavoidably has a close connection with educational improvement at school as their organization. It basically shall determine either school progression or retrogression. Zuber \& Altrichter (2018) claimed that teacher personality like self-efficacy and positive affectivity nurtures openness to educational standard reform. Being more specific, Alexander (2017) has shown that teacher's personality is a trusted party at school to empower students.

A number of research have empirically proven the relation between personality and organizational commitment. A research conducted by Fakhruddin, Ilmi, \& Achmad (2020) showed that personality affects employee job satisfaction and organizational commitment positively. To be more specific, Akbar, Novian, \& Mukhtar (2019) explicated that organization structure, personality and work motivation gives direct influence on organizational commitment. Basnet \& Regmi (2019) also argued that the Big Five Personality traits influence organizational commitment in a positive way.

To be more specific, some research investigate and analyze determinant factors or indicators in positive correlation between 
personality and organizational commitment. Choi, Oh, \& Colbert (2015) observe the relation between the Big Five Personality and the three types of organizational commitment (affective, continuance, and normative). All the personality traits are reported to correlate with all the organizational commitment types. Agreeableness is claimed as the determinant factor. Çelik \& Oral (2016) identified similar connection with the same determinant factor. By way of addition, they discovered that consciousness gives quite big impact on organizational commitment (see also Leephaijaroen, 2016). A research conducted by Syed, Saeed \& Farrukh (2015), and Thiruvarasi \& Kamaraj (2017) either highlighted a significant and positive relation between the five personality traits and organizational commitment dimension. Consciousness and openness are the two facets predicting the relation.

Pointing out personality traits comprehensively, a research of Kumar (2012) noted that openness is the predictor bridging personality and organizational commitment. Yielding similar findings, the research conducted by Njoku, Ebeh, \& Mbaeri (2017) significantly displayed the relation between employee personality and their organizational commitment. They further recommended personality test for employees to assess potential employees. Shabahang \& Amani (2016) exhibited significant relation between personality, specifically on emotional stability, with organizational commitment. Recently, Lee, Park, Back, Hyun, \& Lee (2020) found out expressive personality as a part of emotional stability as the ultimate factor determining the relation between personality and organizational commitment.

The previous research used different indicators or factors to see the correlation between personality and organizational commitment. Other than that, research focusing on civil servant working at vocational high schools have not been frequently reported. Accordingly, the present study is worth to conduct as an attempt to see the impact of personality on organizational commitment which is further expected to advance school quality.

\section{METHODS}

The present research employed quantitative approach with survey method and causal technique or path analysis to find out impact between variables according to the causal model. It portrays two variables in the way they are. Facts are analyzed by looking at independent variable's effect on dependent variable. The research is categorized into inferential as the result of data calculation is used to predict the forthcoming tendency. The analysis connects to the study of estimated error normality test. The path analysis is applied to find out the effect appearing from the two variables, independent variable (exogenous) and dependent variable (endogen). The exogenous variable of the research is personality, and the endogen one is organizational commitment.

The population involved in the present research was civil servants from public vocational high schools. The target population is 2.056 civil servant teachers from 63 public vocational high schools, meanwhile the accessible population is 104 civil servant teachers from 5 public vocational high schools in East Jakarta.

The samples involved in the present research were taken using simple random sampling. 20 respondents were chosen for checking the validity and reliability of questionnaire. After the instrument was valid and reliable, the research data were taken from 83 civil servant teachers.

The instrument used in the present research is questionnaire covering a number of questions generated from personality and organizational indicators. Likert scale (1-5) is utilized with the following alternative answers: (1) strongly disagree, (2) disagree, (3) neutral, (4) agree, and (5) strongly agree. The complete blueprint of each variable is presented in Table 1 . The questionnaire reliability was also checked. The result shows that the questionnaire of both variables are reliable to use as the research instrument. The reliability result of the questionnaire is presented in Table 2 .

Having collected the data, a series of analysis was applied. The data obtained were first analyzed using descriptive statistics analysis continued by inferential analysis. Descriptive statistics were applied to get data characteristic description such as distribution of frequency, histogram, mode, median and standard deviation, while inferential statistics were applied by normality test using Liliefors formula, then completed by path analysis consisting of model 
analysis, test of hypothesis and decision of effect

also applied in advance.

level. Analysis of questionnaire item score was

Table 1. Result of Questionnaire Validity

\begin{tabular}{|c|c|c|c|c|c|}
\hline \multirow{2}{*}{ Variable } & \multirow{2}{*}{ Blueprint } & \multicolumn{2}{|l|}{ Before Validity Test } & \multicolumn{2}{|l|}{ After Validity Test } \\
\hline & & Item number & Total & Item Number & Total \\
\hline \multirow[t]{4}{*}{ Personality } & Extraversion & $1,2,3,4,5,6,7,8,9,10,11$ & 11 & $1,2,3,4,5,6,7,8,9,10$ & 10 \\
\hline & Emotional & $12,13,14,15,16,17,18,19$ & 19 & $11,12,13,14,15,16,17,1$ & 16 \\
\hline & stability & $, 20,21,22,23,24,25,26,2$ & & $8,19,20,21,22,23,24,2$ & \\
\hline & $\begin{array}{l}\text { Openness to } \\
\text { experience }\end{array}$ & $\begin{array}{l}7,28,29,30 \\
31,32,33,34,35,36,37,38 \\
39,40,41,42,43,44,45\end{array}$ & 15 & $\begin{array}{l}5,26 \\
27,28,29,30,31,32,33,34 \\
35,36,37,38,39,40\end{array}$ & 14 \\
\hline & & & 45 & & 40 \\
\hline \multirow[t]{3}{*}{$\begin{array}{l}\text { Organizational } \\
\text { commitment }\end{array}$} & $\begin{array}{l}\text { Employee } \\
\text { engagement } \\
\text { to stay in } \\
\text { organization }\end{array}$ & $1,2,3,4,5,6,7,8,9,10,11$ & 11 & $1,2,3,4,5,6,7,8,9,10,11$ & 11 \\
\hline & $\begin{array}{l}\text { Moral } \\
\text { responsibility }\end{array}$ & $12,13,14,15,16,17,18,19$ & 8 & $12,13,14,15,16,17,18,19$ & 8 \\
\hline & $\begin{array}{l}\text { Individual } \\
\text { loyalty to }\end{array}$ & $\begin{array}{l}20,21,22,23,24,25 \\
26,27,28,29,30,31\end{array}$ & 12 & $\begin{array}{l}20,21,22,23,24,25,26,27 \\
, 28,29,30\end{array}$ & 11 \\
\hline Total & & & 31 & & 30 \\
\hline
\end{tabular}

Table 2. Result of Questionnaire Reliability

\begin{tabular}{lll}
\hline Variable & Coefficient & Status \\
\hline Personality & .979 & Reliable \\
Organizational commitment & .960 & Reliable \\
\hline
\end{tabular}

FINDINGS AND DISCUSSION

\section{Findings}

\section{Test of Descriptive Statistics}

The first step to do in analyzing the data is descriptive statistics calculation covering some of general data of personality and organizational commitment such as mean, standard error, media, mode, standard deviation, sample variance, range and count. The calculation result is displayed in Table 3.

Table 3. Summary of Descriptive Statistics of Personality and Organizational Commitment

\begin{tabular}{crr}
\hline No. Description & $\mathbf{X}$ & $\mathbf{Y}$ \\
\hline 1. Mean & 146.46 & 121.47 \\
2. Standard error & 2.63 & 1.68 \\
3. Median & 144.57 & 121.61 \\
4. Mode & 140.62 & 121.00 \\
5. Standard deviation & 24.00 & 15.31 \\
6. Sample variance & 575.81 & 234.52 \\
7. Range & 103.00 & 60.00 \\
8. Minimum & 97.00 & 90.00 \\
9. Maximum & 200.00 & 150.00 \\
10. Sum & 12,156 & 10,082 \\
11. Count & 83.00 & 83.00 \\
\hline
\end{tabular}

Note: X: Personality; Y: Organizational Commitment
Analysis of Questionnaire Item Score

Each item of the two variable questionnaire was analyzed based on the answer of each blueprint. The result is shown in Table 4 and 5 .

Table 4. Item Score Analysis of Personality Variable (X)

\begin{tabular}{|c|c|c|c|}
\hline No. Indicator & $\begin{array}{l}\text { Total } \\
\text { Item }\end{array}$ & $\begin{array}{l}\text { Average } \\
\text { Answer }\end{array}$ & $\begin{array}{c}\text { Percentage } \\
(\%)\end{array}$ \\
\hline 1. Extraversion & 10 & 3.68 & 33.56 \\
\hline $\begin{array}{l}\text { 2. Emotional } \\
\text { stability }\end{array}$ & 16 & 3.73 & 33.98 \\
\hline $\begin{array}{l}\text { 3. Openness to } \\
\text { experience }\end{array}$ & 14 & 3.56 & 32.46 \\
\hline Total & 40 & 10.97 & 100 \\
\hline
\end{tabular}

Table 4 directs us to a conclusion that emotional stability places the highest rank as the predictor in personality variable. The second indicator to follow is extraversion. The last indicator to predict the civil servant personality is openness to experience. It is simply inferred that to promote civil servant noble personality, the main concern lies on keeping the teachers' emotion stable as the top facet. 
Table 5. Item Score Analysis of Organizational Commitment (Y)

\begin{tabular}{lccc}
\hline No. Indicator & $\begin{array}{c}\text { Total } \\
\text { Item }\end{array}$ & $\begin{array}{c}\text { Average } \\
\text { Answer }\end{array}$ & $\begin{array}{c}\text { Percentage } \\
(\%)\end{array}$ \\
\hline $\begin{array}{l}\text { 1. } \begin{array}{l}\text { Employee } \\
\text { engagement } \\
\text { to stay in } \\
\text { organization }\end{array} \\
\begin{array}{l}\text { Moral } \\
\text { 2. }\end{array}\end{array}$ & 8 & 4.10 & 33.74 \\
$\begin{array}{l}\text { responsibility } \\
\text { 3ndividual loyalty }\end{array}$ & 11 & 3.97 & 32.71 \\
$\begin{array}{l}\text { to organization } \\
\text { Total }\end{array}$ & 30 & 12.15 & $100 \%$ \\
\hline
\end{tabular}

Table 5 explicates that employee engagement to stay in organization gives the highest contribution on organizational commitment. Moral responsibility is the second one to give effect. The lowest one is individual loyalty. It sketches out that the attempt to build the civil servant organizational commitment can be enhanced by more teachers' involvement in any educational activities at schools.

\section{Test of Normality of $Y$ above $X$}

The normality test displays $L_{\text {count }}=.054$ which is less than $L_{\text {table }}=.097(n=83 ; \alpha=.05)$. Considering the result, the data of personality and organizational commitment tend to form a normal curve. This is clear that the null hypothesis stating "the samples are not normally distributed" is rejected. In other words, this is to verbalize that all samples come from a normally distributed population.

The recapitulation of normality test is shown in Table 6. Based on Table 6 containing the values of $L_{\text {count }}$ and $L_{\text {table }}$, it is convinced that all pairs of data from the instrument of organizational commitment above personality are from normal distribution samples.

\section{Test of Significance and Linearity of Regression Coefficient on Organizational Commitment above Personality}

The calculation of regression equation model between organizational commitment and personality results in regression constant $a$ $=76.42$ and regression coefficient $b=.31$. In this manner, the model correlation of simple regression is $\hat{Y}=76.42+.31 X$. Before analyzing the model and using it in drawing conclusion, tests of significance and regression equation linearity were applied. The result of the two tests are arranged in Table 7.

In the regression equation $\hat{Y}=76.42$ $+.31 X$, the test of significance shows $F_{\text {count }}=$ 24.51 which is much greater than $F_{\text {table }} 6.96$ at level of significance $\alpha=.01$. On that ground, the regression linearity is stated to be very significant. For the test of linearity, $F_{\text {count }}=1.28$ is less than $F_{\text {table }}=1.59$ at level of significance $\alpha$ $=.05$. For that reason, the estimated distribution point forms a linear line. The visualization of the distribution point can be vividly viewed in the Figure 1.

The summary of significance test and regression linearity is displayed in Table 8 . Table 8 clearly illustrates that the change of one personality unit shall increase the value of organizational commitment for .31. Then it is definite to say organizational commitment promotion can be enhanced by veracious management of teacher personality.

Table 6. Test of Normality Result (Estimation Error of Regression)

\begin{tabular}{|c|c|c|c|c|c|}
\hline \multirow{2}{*}{$\begin{array}{l}\text { Estimation Error of } \\
\text { Regression }\end{array}$} & \multirow{2}{*}{$n$} & \multirow{2}{*}{$L_{\text {count }}$} & \multicolumn{2}{|c|}{$L_{\text {table }}$} & \multirow{2}{*}{ Decision } \\
\hline & & & $\alpha=.05$ & $\alpha=.01$ & \\
\hline Y above $X$ & 83 & .054 & .097 & .111 & Normal \\
\hline
\end{tabular}

Table 7. ANAVA for Significance and Linearity of Regression Coefficient $\hat{Y}=76.42+.31 X$

\begin{tabular}{|c|c|c|c|c|c|c|}
\hline \multirow{2}{*}{ Variance } & \multirow{2}{*}{$d f$} & \multirow{2}{*}{ SSE } & \multirow{2}{*}{ RMS } & \multirow{2}{*}{$\boldsymbol{F}_{\text {count }}$} & \multicolumn{2}{|c|}{$F_{\text {table }}$} \\
\hline & & & & & $\alpha=.05$ & $\alpha=.01$ \\
\hline Total & 83 & 1243890 & & & & \\
\hline Regression a & 1 & 1224659.33 & & & & \\
\hline Regression $\mathrm{b} / \mathrm{a}$ & 1 & 4467.11 & 4467.11 & $24.51 * *$ & 3.96 & 6.96 \\
\hline Residual & 81 & 14763.56 & 182.27 & & & \\
\hline Standard Error of & 50 & 9952.99 & 199.06 & $1.28 \mathrm{~ns}$ & 1.59 & \\
\hline The Estimate & 31 & 4810.57 & 155.18 & & & \\
\hline
\end{tabular}




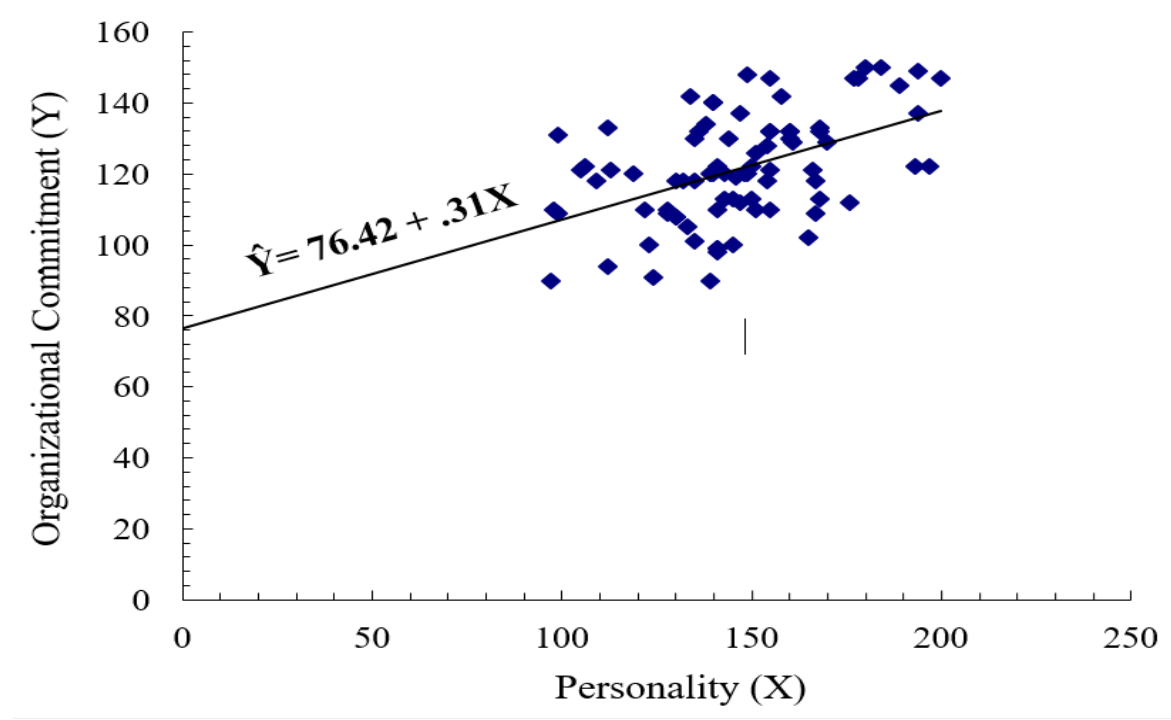

Figure 1. Linear Regression Graphic $\hat{Y}=76.42+.31 X$

Table 8. Summary of Significance Test and Regression Linearity

\begin{tabular}{|c|c|c|c|c|c|c|}
\hline \multirow[b]{2}{*}{ Reg } & \multirow[b]{2}{*}{ Equation } & \multicolumn{2}{|c|}{ Regression Test } & \multicolumn{2}{|c|}{ Linearity Test } & \multirow[b]{2}{*}{ Conclusion } \\
\hline & & $\boldsymbol{F}_{\text {count }}$ & $\begin{array}{c}F_{\text {table }} \\
.01\end{array}$ & $F_{\text {count }}$ & $\begin{array}{c}F_{\text {table }} \\
.05\end{array}$ & \\
\hline$X$ on $Y$ & $\hat{Y}=76.42+.31 X$ & $24.51 * *$ & 6.96 & $\begin{array}{c}1.28 \\
\mathrm{~ns}\end{array}$ & 1.59 & $\begin{array}{l}\text { Very significant/ } \\
\text { Regression is linear }\end{array}$ \\
\hline
\end{tabular}

Note : Reg : Regression; **: Very significant; $n s:$ Non-significant (regression is linier)

\section{Test of Path Significance}

The result of path significance test on two variables is displayed in Table 9. Table 9 unveils that $t_{\text {count }}$ has much higher value compared to $t_{\text {table }}$ at any level of significance (both .05 and $.01)$. This is surely to declare that personality has a positive direct effect on organizational commitment.

\section{Test of Hypothesis}

Having calculated the above analysis, the hypothesis testing was applied. Table 10 assuredly shows that $t_{\text {count }}$ is higher than $t_{\text {table }}(4.329>2.64)$. To this extent, alternative hypothesis is accepted. This concludes undoubtedly that the civil servant personality gives positive direct effect on organizational commitment as an acceptance of alternative hypothesis $\left(H_{1}\right)$.

Table 9. Summary of Path Significance Test

\begin{tabular}{lcccc}
\hline \multirow{2}{*}{ Direct Effect } & \multirow{2}{*}{ Path Coefficient } & $\boldsymbol{t}_{\text {count }}$ & \multicolumn{2}{c}{$\boldsymbol{t}_{\text {table }}$} \\
\cline { 4 - 5 } & & $4.329^{* *}$ & $\mathbf{. 0 5}$ & $\mathbf{. 0 1}$ \\
\hline $\mathrm{X}$ on $\mathrm{Y}$ & .482 & 4.99 & 2.64 \\
\hline
\end{tabular}

Table 10. Summary of Hypothesis Testing

\begin{tabular}{lllll}
\hline Hypothesis & $\begin{array}{l}\text { Statistical } \\
\text { Hypothesis }\end{array}$ & Statistical Test & Decision & Conclusion \\
\hline Personality gives & $H_{o}: \beta_{y x} \leq 0$ & $t_{\text {count }}>t_{\text {table }}$ & $H_{o}$ is rejected & Positive direct effect \\
positive direct effect & $H_{1}: \beta_{y x}>0$ & $(4.329>2.64)$ & & \\
on organizational & & at $\alpha=.01$ & & \\
commitment & & for & & \\
& & $p_{y x}=.482$ & & \\
& & &
\end{tabular}




\section{Discussion \\ Personality Effect on Organizational Commitment}

The present research's objective is to dig up significant relation between personality and organizational commitment of civil servant teachers in vocational schools in Jakarta. Likewise, the analysis of determinant factors or predictors of each variable researched is also targeted.

The analysis of hypothesis testing invents that the teacher personality gives positive and direct impact on organizational commitment. The path analysis applied testifies the direct effect, with value of correlation coefficient .482 and the value of path coefficient .482. Hence, it draws a conclusion that the civil servant teacher organizational commitment is influenced directly by their personality. The further significance of the conclusion is the notion that well teacher personality shall elevate more commendable organizational commitment.

The finding of the present research is commensurate with the following research discovery. To begin with, Choi et al. (2015) had conducted a meta-analysis study deconstructing a number of studies which dispute the effect of personality on organizational commitment. They finally came to a conclusion that personality gives suggestive effect on organizational commitment.

In higher education level, taking a number of staffs working at university as the respondents, Farrukh, Ying \& Mangsori (2017) have proved that almost all personality traits examined to the university staffs represent significant connection with their organizational commitment. The commitments featured in the research are normative, affective and continuance. A research conducted by Chalistya, Putrawan \& Supadi (2019) reported similar result of their investigation but in different commitment focus. Concerning on affective commitment, they discovered affective commitment is influenced by personality directly and significantly. While in secondary education, a research of Widodo \& Damayanti (2020) concluded the existence of personality direct effect on organizational commitment among vocational high school teachers. Giving prominence to the pertinent research, Aspan, Wahyuni, Effendy, Bahri, Rambe \& Saksono (2019) marked out that personality has fortified organizational commitment of university staffs they surveyed.

The present research discovery is either on the testimony of comparable research in banking and finance sector. Abdullah, Omar \& Rashid (2013) verified empirically that bank employee personality can be significantly categorized into positive predictor of their organizational commitment. In Indonesia, the research of Kawiana, Dewi, Martini \& Suardana (2018) explicitly attested that personality variable has a close positive relation with bank employee organizational commitment.

The positive correlation found in this research is either compliant with suchlike research in health and private sector. Mehr \& Dashti (2016) specifically conducted a research to nurses in hospital. They demonstrated eloquent connection between personality and organizational commitment. In private enterprise, Naimi \& Ghafeli (2016) authenticated that all components of personality traits except neuroticism, or also known as emotional stability, affects organizational commitment. To go further, Zareena \& Krithika (2019) illuminated that the big five personality traits play a consequential role in the amplification of employee organizational commitment.

On the top of that, having analyzed relevant research, Nuckcheddy (2018) affirmed that personality will give impact on organizational behavior, notably on the aspects of organizational tolerance, work environment, and work ethics. As concluded and verified in the research of Yunus, Wahab, Ismail \& Othman (2018), personality is dynamic and organized characteristics affecting cognitive aspect, motivation and behavior of employee towards the organization they stay.

Apropos of the present and previous germane research, it is picturesque that well-founded personality shall bring the teachers to perform virtuous organizational commitment especially in case of engagement to stay in organization, willingness to work and responsibility to finish their work, and allegiance to their organization. To a greater degree, the present research sharpens the main finding that nurturing teacher organizational commitment cannot only be stimulated by regional allowance, but also by solicitude acts on their personality. 


\section{Predictors of Personality Affecting Organizational Commitment}

From the Big Five Personality traits proposed by Goldberg (1993), the present research adapts three traits as the predictors involving extraversion, emotional stability and openness to experience.

Supporting the main finding discussed earlier, it is exhibited that the highest determining predictor of the civil servant teacher personality is emotional stability, with 3.73 average answer or $33.98 \%$. This is honoring the finding revealed by Shabahang \& Amani (2016) who conducted the research to school principals. They noticed emotional stability as a critical factor in principals' commitment to their organization. Setting out even further, they designated how organizational commitment has a tight relation with positive job performance. Exposing the identical result, Lee et al. (2020) viewed a fact that emotional stability among hospitality industry workers, i.e. expressive personality, has a pivotal function to raise their organizational commitment, moreover in its conjunction with commitment in service quality.

The second highest factor is extraversion, contributing $33.56 \%$ to the whole percentage with average answer per indicator 3.68. This predictor is in proportion to the research conducted by Gridwichai, Kulwanich, Piromkam \& Kwanmuangvanich (2020) to some pharmacists. The fact depicted the level of extraversion as the starting point of advancing to much higher career. Easy recognition by other employees also stands as the point characterized by extraversion. Abdullah et al. (2013) conveyed coequal result after inquiring into level of extraversion of bank employee. The employee extraversion is claimed to give positive effect on their commitment to the bank. The study of Khoeini \& Attar (2015) had also proven how employees' extraversion of a hospital positively impacts their commitment to their workplace.

The last factor is openness to experience with average per indicator 3.56 or $32.64 \%$ of the total percentage. Similar result has been attested by Acaray \& Yildirim (2017). They researched private school teachers and found out that their openness attitude brings positive effect on cognitive and affective commitment. Having examined systematically the connection of openness with organizational commitment to a university staffs, Khiavi, Dashti \& Mokhtari (2016) drew a conclusion that openness is believed as a positive predictor on organizational commitment.

The present research finding symbolizes that personality traits of the civil servant teachers are noteworthy. The preservation of their emotional stability, extraversion and openness to experience should be done to promote the growth of commitment and responsibility to schools.

\section{Predictors of Organizational Commitment}

There are three factors used to measure the organizational commitment of the civil servant teachers. They comprise of employee engagement to stay in organization, moral responsibility and individual loyalty to organization.

The first predictor to determine organizational commitment in this research is employee engagement to stay in organization. The average score is 4.10 with percentage $33.74 \%$. The result is in agreement with the research result reported by Rameshkumar (2019). He surveyed a number of mariners and concluded that there is a positive relation between mariner engagement and all types of organizational commitment except continuance commitment. Carrying out a quantitative survey to professional accountants, Tasleem \& Ishaq (2016) proposed indistinguishable result, specifying that employee engagement or what they called as job involvement influences organizational commitment positively and significantly. To be more detail, Suryani (2018) postulated that from employees' perception, their engagement contributes to their commitment. While the perception of employers, opportunity to step on higher position or career and team work experience are the predictors of organizational commitment.

The second observed factor is moral responsibility. The score of average per indicator is $4.08(33.55 \%)$. The finding is in harmony with a report from Prutina (2016) after examining employee organizational commitment in a multinational company. The study summarized the employees' perception of responsibility to give impact on their organizational commitment. Presenting more detail explication, Turker (2009), having tested business professionals as the respondents, professed either social or nonsocial responsibility is a revealing predictor on 
organizational commitment. While Ahmed \& Tahir (2019) conducted a research to employees of public companies and found out a tendency that their economics responsibility side is also influential to organizational commitment notably affective commitment.

The last facet is individual loyalty to organization. The average score is 3.97 or $32.71 \%$. Corresponding to the previous study result, after analyzing the data taken from a company employees, Iqbal, Tufail \& Lodhi (2015) resumed positive significant correlation between employee loyalty and their commitment to the company. Examining employees of heavy equipment dealership, Nasiri, Najafbagy \& Nasiripour (2015) also pointed out similar finding, and even claimed that individual loyalty of the dealership positively impacts on quality service to customers. A survey done by Mahalingam \& Suresh (2018) to an IT company employees also confessed the resembling result.

Those three factors indicate that to maintain the organizational commitment of civil servant teachers, the school management is supposed to provide more portion and opportunity for them to involve actively in any school activities which at the end will improve their sense of belonging to school. Other than that, giving good model and creating reasonable as well as steady policy are suggestive.

\section{CONCLUSIONS}

The result of path analysis shows that $t_{\text {count }}$ is higher than $t_{\text {table }}(4.329>2.64)$. The present research then concludes that there is a positive direct effect of personality on organizational commitment of the civil servant teachers. It further means the enhancement of personality will develop civil servant teachers' organizational commitment. Correspondingly, this result is in consonance with a number of previous relevant research.

The supporting conclusion is the indicators to determine personality. The first is emotional stability with percentage $33.98 \%$. The second facet to predict the personality is extraversion, giving contribution $33.56 \%$. The last factor is openness to experience with $33.56 \%$ contribution to the whole percentage. The implication of this finding insinuates school principals to be more solicitous to the teachers' personality specifically stability of teachers' emotion as the empowerment for them to work in intense electrifying environment.

The next supporting result is factors to affect organizational commitment. After being calculated, it is identified the top indicator is employee engagement to stay in organization (33.74\%). The second one is moral responsibility $(33.55 \%)$. The last predictor with the lowest percentage $(32.71 \%)$ is individual loyalty to organization. This implies a necessity for school principals to keep engaging their teachers in school work and duties. Providing honorable role model and vigorous rules or policy are either vitally important.

The present research uses three foci of predictors for each variable. It is highly suggested for the future research to apply all traits of the Big Five Personality to measure the projected variable. Specifying the type of organizational commitment is also admonished. Besides, surveying respondents with much broader criteria, i.e. non-permanent or honorary teachers, is worth to conduct.

\section{ACKNOWLEDGEMENT}

We express our sincere gratitude to the Head of STKIP Kusuma Negara and Head of Civics Education Study Program for any support, guidance and help for us to conduct the research. We are also thankful to all civil servant teachers and principals of Public Vocational High Schools in East Jakarta for their participation during the research.

\section{REFERENCES}

Abdullah, H. (2009). Major challenges to the effective management of human resource. The Journal of International Social Research, 2(8), 11-25. http:// sosyalarastirmalar.com/cilt2/sayi8pdf/ abdullah_haslinda1.pdf.

Abdullah, I., Omar, R., \& Rashid, Y. (2013). Effect of personality on organizational commitment and employees' performance: Empirical evidence from banking sector of Pakistan. Middle-East Journal of Scientific Research, 18(6), 759-766. https://www. idosi.org/mejsr/mejsr18(6)13.htm.

Acaray, A., \& Yildirim, S. (2017). The impact of personality traits on organizational cynicism in the education sector. World 
Journal of Entrepreneurship, Management and Sustainable Development, 13(1), 65-76. $\quad$ https://doi.org/10.1108/ wjemsd-12-2015-0051.

Ahmed, N., \& Tahir, N. S. (2019). Employees' perception on corporate social responsibility practices and affective commitment. Journal of Accounting Research Organization and Economics, 2(1), 41-53. https://doi.org/10.24815/ jaroe.v2i1.13274.

Akbar, M., Novian, Z., \& Mukhtar, M. (2019). The effect of organizational structure, personality and work motivation on teacher organization commitments on International Islamic Education Council Foundation in Jakarta and Bekasi. Journal of Science and Science Education, 3(1), 19-31. https://ejournal.uksw.edu/josse/ article/view/2742.

Alexander, L. S. (2017). The effect of secondary teacher personality on educational empowerment (Dissertation, Walden University). https://scholarworks. waldenu.edu/dissertations/3423/.

Aspan, H., Wahyuni, E. S., Effendy, S., Bahri, S., Rambe, M. F., \& Saksono, F. B. (2019). The moderating effect of personality on organizational citizenship behavior: The case of university lecturers. International Journal of Recent Technology and Engineering, 8(2S), 412-416. https:// www.ijrte.org/wp-content/uploads/ papers/v8i2S/B10600782S19.pdf.

Basnet, D. M., \& Regmi, M. P. (2019). The correlational study of the personality traits, organizational commitment and self-efficacy of saving and credit cooperative societies (SACCOS) employees of Kathmandu. Open Journal of Business and Management, 7(2), 455-479. https:// doi.org/10.4236/ojbm.2019.72031.

Çelik, G. T., \& Oral, L. E. (2016). Big five and organizational commitment-The sase of Turkish construction professionals. Human Resource Management Research, 6(1), 6-14. http://article.sapub. org/10.5923.j.hrmr.20160601.02.html.
Chalistya, Y. A., Putrawan, I. M., \& Supadi, S. (2019). The effect of personality and integrity to affective organizational commitment. International Journal of Engineering Technologies and Management Research, 6(1), 84-93. https://doi.org/10.5281/zenodo.2563245.

Choi, D., Oh, I. S., \& Colbert, A. E. (2015). Understanding organizational commitment: Ameta-analytic examination of the roles of the five-factor model of personality and culture. Journal of Applied Psychology, 100(5), 1542-1567. https://doi.org/10.1037/ap10000014.

Fakhruddin, F., Ilmi, Z., \& Achmad, N. G. (2020). The influence of personality and organizational commitment and work engagement to employee satisfaction and employee performance DPRD Samarinda City. International Journal of Economics, Business and Accounting Research, 4(2), 161-170. $\quad$ https://jurnal.stie-aas.ac.id/ index.php/IJEBAR/article/view/1049.

Farrukh, M., Ying, C. W., \& Mansori, S. (2017). Organizational commitment: an empirical analysis of personality traits. Journal of Work-Applied Management, 9(1), 18-34. https://doi.org/10.1108/jwam-12-2016$\underline{0026}$.

Goldberg, L. R. (1993). The structure of phenotypic personality traits. American Psychologist, 48(1), 26-34. https://doi. org/10.1037/0003-066X.48.1.26.

Gridwichai, P., Kulwanich, A., Piromkam, B., \& Kwanmuangvanich, P. (2020). Role of personality traits on employees job performance in pharmaceutical industry in Thailand. Systematic Reviews in Pharmacy, 11(3), 185-194. http://www. sysrevpharm.org/index.php?mno=92367.

Iqbal, A., Tufail, M. S., \& Lodhi, R. N. (2015). Employee loyalty and organizational commitment in Pakistani organizations. Global Journal of Human Resource Management, 3(1), 1-11. https://www. eajournals.org/journals/global-journalof-human-resource-management-gjhrm/ vol-3issue 1 january-2015/employee- 
loyalty-organizational-commitmentpakistani-organizations/.

Kawiana, I. G. P., Dewi, L. K. C., Martini, L. K. B., \& Suardana, I. B. R. (2018). The influence of organizational culture, employee satisfaction, personality, and organizational commitment towards employee performance. International Research Journal of Management, 5(3), 35-45. https://sloap.org/journals/index. php/irjmis/article/view/166.

Khiavi, F. F., Dashti, R., \& Mokhtari, S. (2016). Association between organizational commitment and personality traits of faculty members of Ahvaz Jundishapur University of Medical Sciences. Electronic Physician, 8(3), 2129-2135. https://doi. org/10.19082/2129.

Khoeini, F., \& Attar, B. N. (2015). Personality characteristics and organizational commitment in Iranian employees. International Journal of Scientific Reports, 1(1), 61-64. https://doi.org/10.18203/ issn.2454-2156.intjscirep20150203.

Kinicky, A., \& Fugate, M. (2016). Organizational behavior: A practical-problem solving approach. New York, NY: McGraw-Hill Education.

Kumar, N. (2012). Relationship of personal \& organizational values with organizational commitment. The Indian Journal of Industrial Relations, 48(2), 306-314. https://www.jstor.org/stable/23509840.

Kumorotomo, W. (2011). Tunjangan kinerja daerah (TKD) dan upaya peningkatan kinerja pegawai: Kasus di provinsi Gorontalo dan provinsi DKI Jakarta. [Regional performance allowance and effort to improve officers' performance: A case in Gorontalo province and Jakarta Capital City]. Jurnal Kebijakan Dan Manajemen PNS, 5(1), 22-34. https:// jurnal.bkn.go.id/index.php/asn/article/ view/115/70.

Lee, S., Park, J., Back, K.-J., Hyun, H., \& Lee, S. H. (2020). The role of personality traits toward organizational commitments and service quality commitments. Frontiers in Psychology, 11(631), 1-11. https://doi. org/10.3389/fpsyg.2020.00631.

Leephaijaroen, S. (2016). Effects of the bigfive personality traits and organizational commitments on organizational citizenship behavior of support staff at Ubon Ratchathani Rajabhat University. Kasetsart Journal of Social Sciences, 37(2), 104-111. https://doi.org/10.1016/j. kjss.2015.03.002.

Lovakov, A. (2016). Antecedents of organizational commitment among faculty: An exploratory study. Tertiary Education and Management, 22(2), 149170. https://doi.org/10.1080/13583883.20 16.1177583.

Mahalingam, S., \& Suresh, M. (2018). The impact of organizational commitment on employee loyalty in IT industry with reference to Coimbatore City. International Journal of Research in Engineering, Science and Management, 1(5), 55-59. http://www.ijresm.com/ vol1 iss5May18/IJRESM15_16.pdf.

McShane, S. L., \& von Glinow, M. A. (2015). Organizational behavior: Emerging knowledge and practice for the real world $\left(7^{\text {th }}\right.$ ed). New York, NY: McGraw-Hill Education.

Mehr, N. P., \& Dashti, F. (2016). Determining the relationship between organizational commitment and personality trait of nursing managers (Case study: Selected hospitals in Isfahan province in 2015). International Journal of Medical Research \& Health Sciences, 5(S), 114-120. https:// www.ijmrhs.com/abstract/determiningthe-relationship-between-organizationalcommitment-and-personality-trait-ofnursing-managers-case-study-sele-2884. html.

Naimi, E. A., \& Ghafeli, A. (2016). Explain the relationship between personality and organizational commitment in the office staff of the National Logistics Company South Oil. Journal of Business \& Financial Affairs, 5(1), 1-4. https://doi. 
org/10.4172/2167-0234.1000166.

Nasiri, S., Najafbagy, R., \& Nasiripour, A. A. (2015). The impact of employee loyalty on the success of commercial organizations: A case study on the dealerships of heavy equipment in Iran. Journal of Human Resource Management, 3(3), 27-32. https://doi.org/10.11648/j. jhrm.20150303.12.

Njoku, E. C., Ebeh, R. E., \& Mbaeri, S. O. (2017). Personality traits as predictors of organizational commitment among public and private sector employees in Enugu, Nigeria. In British Journal of Psychology Research, 5(2), 9-23. https:// www.eajournals.org/journals/britishjournal-of-psychology-research-bjpr/ vol-5-issue-2-april-2017/personalitytraits-predictors-organizationalcommitment-among-public-privatesector-employees-enugu-nigeria/.

Nuckcheddy, A. (2018). The effect of personality on motivation and organisational behaviour. Psychology and Behavioral Science International Journal, 9(2), 1-5. https://doi.org/10.19080/ pbsij.2018.09.555760.

Pramudjono, P. (2015). Pengaruh gaya kepemimpinan, tingkat hierarki moral, dan motivasi terhadap komitmen guru. [The influence of the leadership styles, moral hierarchy levels, and motivation towards teacher's commitment]. Cakrawala Pendidikan, 34(3), 449-456. https://doi. org/10.21831/cp.v3i3.7408.

Prutina, Ž. (2016). The effect of corporate social responsibility on organizational commitment. Management Management: Journal of Contemporary Management, 21(Special Issue), 227-248. https://hrcak. srce.hr/155071.

Rameshkumar,M.(2019). Employee engagement as an antecedent of organizational commitment - A study on Indian seafaring officers. Asian Journal of Shipping and Logistics, 36(3), 105-112. https://doi. org/10.1016/j.ajsl.2019.11.003.
Robbins, S. P., \& Judge, T. (2017). Organizational behavior. California, CA: Pearson Education.

Shabahang, M. J., \& Amani, M. (2016). The relationship between personality factors and organizational commitment of Iranian primary school principals. International Journal of Psychology and Educational Studies, 3(3), 50-59. https://doaj.org/article/ f354b10c773440c697b6cf355878d6b2.

Situmorang, B. (2014). Faktor-faktor penentu komitmen organisasi kepala SMK (Studi kasus pada SMK di kota Medan). [Determining factors of the vocational school principals' organization commitment (A case study in vocational schools in Medan Municipality)]. Cakrawala Pendidikan, 33(1), 39-49. https://doi.org/10.21831/cp.v1i1.1860.

Suriansyah, A. (2014). Hubungan budaya sekolah, komunikasi, dan komitmen kerja terhadap kinerja guru sekolah dasar negeri. [The relationship between school culture, communication, and commitment and the state elementary school teachers' performance]. Cakrawala Pendidikan, 33(3), 358-367. https://doi.org/10.21831/ cp.v3i3.2380.

Suryani, I. (2018). Factors affecting organizational commitment. Jurnal Manajemen Inovasi, 9(1), 26-34. http://erepository.unsyiah.ac.id/JInoMan/article/ view/11418.

Syed, N., Saeed, A., \& Farrukh, M. (2015). Organization commitment and five factor model of personality: Theory recapitulation. Journal of Asian Business Strategy, 5(8), 183-190. http://www.aessweb.com/journals/ August2015/5006/3157.

Tasleem, I., \& Ishaq, H. M. (2016). Factors affecting organizational commitment: Study of accountant's firm of Pakistan. Science International, 28(5), 4853-4858. http://www.sci-int.com/Search?catid=75.

Thiruvarasi, M., \& Kamaraj, M. (2017). 
Relationship between big five personality and organizational commitment: A study among executives in a public sector organization. International Journal of Development Research, 7(12), 17617-17623. https://www. journalijdr.com/relationship-betweenbig-five-personality-and-organizationalcommitment-study-among-executives.

Turker, D. (2009). How corporate social responsibility influences organizational commitment. Journal of Business Ethics, 89(2), 189-204. https://doi.org/10.1007/ s10551-008-9993-8.

Widodo, W., \& Damayanti, R. (2020). Vitality of job satisfaction in mediation: The effect of reward and personality on organizational commitment. Management Science Letters, 10(2020), 2131-2138. https://doi. org/10.5267/j.msl.2020.1.016.
Yunus, M. R. B. M., Wahab, N. B. A., Ismail, M. S., \& Othman, M. S. (2018). The importance role of personality trait. International Journal of Academic Research in Business and Social Sciences, 8(7), 1028-1036. https://doi.org/10.6007/ ijarbss/v8-i7/4530.

Zareena, J., \& Krithika, M. (2019). The moderating role of big five personality factors in the relationship between employee morale and work commitment. International Journal of Innovative Technology and Exploring Engineering, 8(12), 1249-1251. https://doi. org/10.35940/ijitee.L3980.1081219.

Zuber, J., \& Altrichter, H. (2018). The role of teacher characteristics in an educational standards reform. Educational Assessment, Evaluation and Accountability, 30(2), 183-205. https://doi.org/10.1007/s11092018-9275-7. 